\title{
Risk Factors for Different Types of Traumatic Injuries in Primary Teeth
}

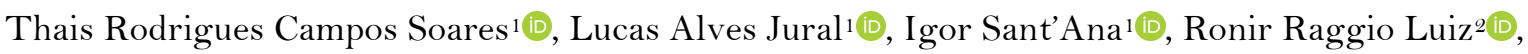

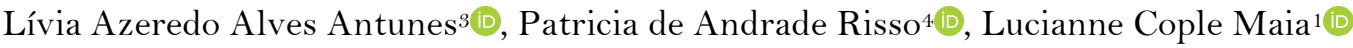

\begin{abstract}
${ }^{1}$ Department of Pediatric Dentistry and Orthodontics, School of Dentistry, Federal University of Rio de Janeiro, Rio de Janeiro, RJ, Brazil.

2Institute of Public Health Studies, Federal University of Rio de Janeiro, Rio de Janeiro, RJ, Brazil.

${ }^{3}$ Department of Specific Training, School of Dentistry, Fluminense Federal University, Niterói, RJ, Brazil.

${ }^{4}$ Department of Dental Clinic, School of Dentistry, Federal University of Rio de Janeiro, Rio de Janeiro, RJ, Brazil.
\end{abstract}

Author to whom correspondence should be addressed: Lucianne Cople Maia, Universidade Federal do Rio de Janeiro, Centro de Ciências da Saúde, Faculdade de Odontologia, Disciplina de Odontopediatria, Caixa Postal 68066, Cidade Universitária, Rio de Janeiro, RJ, Brazil. 21941-971. Phone: +552139382101. E-mail: rorefa@terra.com.br.

Academic Editors: Alessandro Leite Cavalcanti and Wilton Wilney Nascimento Padilha

Received: 23 August 2019 / Accepted: 04 March 2020 / Published: 20 March 2020

How to cite this article: Soares TRC, Jural LA, Sant'Ana I, Luiz RR, Antunes LAA, Risso PA, et al. Risk factors for different types of traumatic injuries in primary teeth. Pesqui Bras Odontopediatria Clín Integr. 2020; $20:$ e5150. https://doi.org/10.1590/pboci.2020.051

\begin{abstract}
Objective: To evaluate traumatic dental injuries (TDI) in primary teeth and the association of gender and age with different injuries. Material and Methods: Records of patients with TDI in primary teeth were included. The following parameters were registered: gender and age, place of trauma, cause of trauma, affected tissue and tooth, number of injured teeth, type of injury, and gingival and bone damage. A logistic regression analysis was performed to explore the interaction between gender and age on the occurrence of types of injuries $(\mathrm{p} \leq 0.05)$. Results: The total of 721 records were evaluated and 370 records were included, being $61.6 \%$ boys and $60.5 \%$ children aged $0-3$ years old, with 658 primary teeth affected. The support tissue was most affected (496/658), followed by dental tissue (139/658). Enamel/dentine fracture with pulp exposure $(n=51)$ and intrusion $(n=131)$ were the most common injuries of dental and support tissues, respectively. In general, boys suffered more traumas than girls, regardless of the age range. As for concussion, logistic regression confirms that gender and age are also influencers. Girls $(\mathrm{OR}=1.822, \mathrm{CI}=$ 1.050-3.164, $\mathrm{p}=0.033)$ in the 4-6 year age group $(\mathrm{OR}=2.15, \mathrm{CI}=1.239-3.747, \mathrm{p}=0.007)$ are more likely to have concussions. Children age 4-6 years were less likely to suffer an intrusion $(\mathrm{OR}=0.496$; $\mathrm{CI}=0.278-$ 0.886; $\mathrm{p}=0.018$ ). Conclusion: Gender and age influence concussion and intrusion in the primary teeth.
\end{abstract}

Keywords: Child; Tooth, Deciduous; Tooth Injuries; Risk Factors. 


\section{Introduction}

Traumatic dental injuries (TDI) are common in children and adolescents, relevant to public health, due to treatment costs and the consequences for oral health [1,2]. Such injuries can directly or indirectly influence the patient's quality of life in terms of aesthetic, functional and psychological changes, which can result in socialization problems [2-4]. Moreover, injuries are the reason for the first visit to the dentist in $40 \%$ of pre-school aged children [5].

Children with trauma in their primary incisors have more developmental disorders in their permanent successors than individuals without previous trauma. The child's age at the time of injury and severity of injury are associated with more serious developmental disorders. This fact only reinforces the importance of health promotion policies, which must be strengthened to encourage the implementation of preventive strategies to reduce the frequency of TDI in pre-school children [6].

Prevalence involving primary teeth can range from $16.3 \%$ to $62.1 \%$ [7,8]. In surveys conducted in communities and schools, under-diagnosis of dental trauma often occurs, since they are observed only as sequels after a trauma [9]. Several studies have shown a predilection for males and for younger children [714]; however, no reports exist in the literature evaluated at the same time reports were released regarding the relationship between gender and age with a different type of injury in primary teeth.

Thus, the aim of this study was to determine the frequency of TDI and the association of gender and age with different types of injuries in primary teeth of patients who attended the reference Dental Trauma Surveillance Center (DTSC) at the School of Dentistry at Federal University of Rio de Janeiro, Brazil.

\section{Material and Methods}

Type of Study and Sampling

This retrospective study evaluated dental records of children aged between 0 and 12 years old, who attended DTSC from 2005 to 2010 . The inclusion criteria included systemically healthy patients with a history of TDI in primary teeth. Records of children with mental disabilities and those with incomplete data were excluded from the present study.

\section{Clinical and Radiographic Examination and Documentation}

Professionals performing the initial examinations and emergency treatments were MSc dental students who had received prior training and were supervised by a professor during the procedures. The MSc students were trained with theoretical and practical classes on diagnosis and treatment of dental trauma using clinical and radiographic images.

At the time of injury, the following parameters were registered on trauma charts: the patient's gender and age (0-3 years old; 4-6 years-old), place of trauma, cause of trauma, affected tissue and tooth, number of injured teeth, type of injury, and gingival and bone damage. For each tooth, clinical information was recorded, which included the color of the clinical crown, dislocation, mobility, tenderness to percussion, percussion tone. The TDI diagnostic was made per Andreasen's classification [1]. Teeth that presented more than one type of injury were classified per their severity. The authors considered luxations more severe than fractures, except for fracture of enamel and dentin with pulp exposure that was considered more severe than concussion and subluxation. 
SPSS Statistical Software, version 21.0 (SPSS Inc., Chicago, IL, USA) was used. A logistic regression analysis was performed to explore the interaction between gender and age on the occurrence of types of injuries. Logistic regression was performed in General Linear Models (GEE) to consider the internal correlation of the observations of each patient's teeth $(\mathrm{p} \leq 0.05)$.

Ethical Aspects

The study was approved by the local Research Ethics Committee (Protocol No. 1.885.653). All the subjects were treated in accordance with the Helsinki Declaration, and each subject participating in this study, along with their parents, signed consent forms with detailed information.

\section{Results}

Of the total sample of 721 records, $370(51.3 \%)$ met the criteria for inclusion in the study. The final sample had $61.6 \%$ boys and $60.5 \%$ of children aged $0-3$ years old. The most common cause was fall from own height (51.1\%) and the most common place of occurrence was at home $(63.8 \%)$ (Table 1$)$

Table 1. Features of patients with traumatic dental injury.

\begin{tabular}{lcc}
\hline \multicolumn{1}{c}{ Variables } & N & \% \\
\hline Gender & & 38.4 \\
Female & 142 & 61.6 \\
Male & 228 & \\
Age & 224 & 60.5 \\
O-3 Years & 146 & 39.5 \\
4-6 Years & & \\
Place of Trauma & 59 & 15.9 \\
Street & 236 & 63.8 \\
Home & 41 & 11.1 \\
School & 18 & 4.9 \\
Others & 16 & 4.3 \\
Not Answered & & \\
Cause of Trauma & 189 & 51.1 \\
Fall From Height & 80 & 21.6 \\
Others Falls & 13 & 3.5 \\
Sporting Accidents & 4 & 1.1 \\
Car Accident & 65 & 17.6 \\
Others & 19 & 5.1 \\
Not Answered & 370 & 100.0 \\
$\quad$ Total & & \\
\hline$\quad$ & & \\
\hline & &
\end{tabular}

In our final sample of 370 patients, in which 658 primary teeth were affected. The boys $(61.9 \%)$ had more teeth affected than girls $(38.1 \%)$. The maxillary central incisors $(80.2 \%)$ were the most commonly affected teeth in both genders. The support tissue was most affected (496/658), followed by dental tissue (139/658) and dental tissue and support (23/658).

Enamel/dentine fracture with pulp exposure $(n=51)$ and intrusive luxation $(n=131)$ were the most common injuries of dental and support tissues, respectively. In general, boys suffer more traumas than girls, regardless of age range. However, girls suffer more fractures of dentin enamel without pulp exposure in all evaluated age groups. In addition, girls aged 4-6 years suffer more concussions, while those aged 0-3 years suffer more subluxation than boys (Table 2 ). 
Table 2. Distribution of the presence of types of injuries according to gender and age.

\begin{tabular}{|c|c|c|c|}
\hline Type of Injury & Age (Years) & $\begin{array}{l}\text { Male } \\
\text { N (\%) }\end{array}$ & $\begin{array}{c}\text { Female } \\
\mathrm{N}(\%)\end{array}$ \\
\hline \multirow{2}{*}{ Enamel Fracture $(n=47)$} & $0-3(n=32)$ & $23(71.9)$ & $9(28.1)$ \\
\hline & $4-6(n=15)$ & $11(73.3)$ & $4(26.7)$ \\
\hline \multirow{2}{*}{ Enamel/Dentine Fracture without Pulp Exposure $(n=42)$} & $0-3(n=32)$ & $15(46.9)$ & $17(53.1)$ \\
\hline & $4-6(n=10)$ & $4(40.0)$ & $6(60.0)$ \\
\hline \multirow{2}{*}{ Enamel/Dentine Fracture with Pulp Exposure $(n=51)$} & $0-3(n=38)$ & $27(71.1)$ & $11(28.9)$ \\
\hline & $4-6(n=13)$ & $12(92.3)$ & $1(7.7)$ \\
\hline \multirow{2}{*}{ Concussion $(n=109)$} & $0-3(n=50)$ & $30(60.0)$ & $20(40.0)$ \\
\hline & $4-6(n=59)$ & $25(42.4)$ & $34(57.6)$ \\
\hline \multirow{2}{*}{ Subluxation $(\mathrm{n}=81)$} & $0-3(n=40)$ & $14(35.0)$ & $26(65.0)$ \\
\hline & $4-6(n=41)$ & $27(65.9)$ & $14(34.1)$ \\
\hline \multirow{2}{*}{ Lateral Luxation $(\mathrm{n}=86)$} & $0-3(n=49)$ & $29(59.2)$ & $20(40.8)$ \\
\hline & $4-6(n=37)$ & $30(81.1)$ & $7(18.9)$ \\
\hline \multirow{2}{*}{ Extrusion Luxation $(\mathrm{n}=37)$} & $0-3(n=20)$ & $13(65.0)$ & $7(35.0)$ \\
\hline & $4-6(n=17)$ & $9(52.9)$ & $8(47.1)$ \\
\hline \multirow{2}{*}{ Intrusive Luxation $(\mathrm{n}=131)$} & $0-3(n=96)$ & $64(66.7)$ & $32(33.3)$ \\
\hline & $4-6(n=35)$ & $22(62.9)$ & $13(37.1)$ \\
\hline \multirow{2}{*}{ Avulsion $(n=74)$} & $0-3(n=44)$ & $28(63.8)$ & $16(36.4)$ \\
\hline & $4-6(n=30)$ & $24(80.0)$ & $6(20.0)$ \\
\hline
\end{tabular}

As for concussion, logistic regression confirms that both gender and age influence the occurrence of some types of injuries. Girls $(\mathrm{OR}=1.822, \mathrm{CI}=1.050-3.164, \mathrm{p}=0.033)$ in the 4-6-year age group $(\mathrm{OR}=2.15$, $\mathrm{CI}=1.239-3.747, \mathrm{p}=0.007)$ are more likely to have concussions. Children at age 4-6 years were less likely to suffer an intrusive luxation $(\mathrm{OR}=0.496 ; \mathrm{CI}=0.278-0.886 ; \mathrm{p}=0.018)$. Logistic regression did not confirm the influence of gender and age on the occurrence of other injuries (Table 3).

Table 3. Interaction between gender and age on the occurrence of types of injuries.

\begin{tabular}{|c|c|c|c|c|c|c|}
\hline \multirow{3}{*}{ Dependent Variable } & \multicolumn{6}{|c|}{ Independent Variable } \\
\hline & \multicolumn{3}{|c|}{ Age (4-6 Years) } & \multicolumn{3}{|c|}{ Gender (Female) } \\
\hline & p-valor & OR & IC $(95 \%)$ & p-valor & OR & IC $(95 \%)$ \\
\hline Enamel Fracture & 0.363 & 1.003 & $0.328-1.502$ & 0.186 & 0.592 & $0.272-0.287$ \\
\hline Enamel/Dentine Fracture without Pulp Exposure & 0.095 & 0.475 & $0.198-1.137$ & 0.073 & 2.025 & $0.937-4.375$ \\
\hline Enamel/Dentine Fracture with Pulp Exposure & 0.095 & 0.495 & $0.217-1.129$ & 0.067 & 2.166 & $4.948-1.055$ \\
\hline Concussion & $0.007^{*}$ & 2.155 & $1.239-3.747$ & 0.033 & 1.822 & $1.050-3.164$ \\
\hline Subluxation & 0.060 & 1.752 & $0.976-3.148$ & 0.067 & 1.733 & $0.961-3.120$ \\
\hline Lateral Luxation & 0.551 & 1.196 & $0.662-2.157$ & 0.337 & 0.714 & $0.360-1.417$ \\
\hline Extrusive Luxation & 0.457 & 1.353 & $0.608-3.013$ & 0.778 & 1.124 & $0.500-2.524$ \\
\hline Intrusive Luxation & $0.018^{*}$ & 0.496 & $0.278-0.886$ & 0.413 & 0.795 & $0.459-1.377$ \\
\hline Avulsion & 0.848 & 1.058 & $0.590-1.898$ & 0.192 & 0.657 & $0.349-1.233$ \\
\hline
\end{tabular}

Logistic regression was performed in General Linear Models (GGE) to consider the internal correlation of the observations of each patient's teeth $(\mathrm{p} \leq 0.05)$. Statistically significant $(\mathrm{p} \leq 0.05)$.

\section{Discussion}

Brazil is considered one of the countries that most research about TDI. Despite the number of studies about dental trauma in primary teeth, better methodological designs are needed to offer a more substantial contribution to clinical practice and contribute to the establishment of preventive strategies to help reduce TDI frequency and its impact on the quality of life of children and their families $[15,16]$. 
In the present study, from the total number of patients included, $51.3 \%$ had one or more traumatized primary teeth. The frequency of trauma found in this study was higher than those found in the literature $[12,14,17,18]$. This high frequency is related to the fact that DTSC is a center of reference for the treatment of dental trauma in the city of Rio de Janeiro, making the diagnosis more reliable. When observing only fractures, discoloration and lost teeth, an under-diagnosis of traumatic injuries occurs [9]. In the evaluated sample, boys and children aged $0-3$ years experienced the most dental injuries, corroborating with previous studies $[7,14,17,19]$. The injuries increase substantially with the child's first efforts to crawl and walk, due to lack of experience and coordination. The peak of incidences occurs from $2-4$ years of age, followed by a second peak from 8-10 years of age [1].

In accordance with the literature [7,14,17-19], fall from height was the most prevalent cause of trauma in primary teeth and the most common place being in the house. These facts are comprehensible since most preschool children tend to spend most of their time at homes, under the guardianship of family or caregivers, as in most cases they do not have any social commitments. Moreover, as mentioned, children at this age are still maturing their motor skills and tend to suffer falls mostly from height.

The upper arch, due to its anatomic location, is itself more prone to suffering injuries and, in this sense, the central incisors followed by the upper lateral teeth are the most frequently affected teeth, as reported in various studies [7,18-21], including the present study.

Support tissue was the most affected in this study, which can be explained because of the resilient bone surrounding the primary teeth. The intrusion was the most common injury in support tissues. These results are contradictory to previous studies [7,17-19,22,23]. Because it is a referral center, the search for treatment is higher in cases of more severe injuries.

The cross-sectional design does allow examining the temporal relationship between variables. The sample was not representative of the population, since they recruited in a dental clinic of the university service. Nonetheless, the study provided an interesting evaluation about risk factors for dental trauma in deciduous teeth.

Several studies in the literature report on factors considered at risk for the occurrence of trauma in the primary dentition, but none of them compare these factors according to the different types of injuries [7-13,1723]. Gender and age are considered the main confounding factors related to dental trauma in the primary dentition [7-14,17-24]. To further explore these factors, logistic regression was used to evaluate the relationship between the different types of injuries and gender (female and male), as well as the children's age group (0-3 years / 4-6 years).

Children aged 4-6 years were more likely to suffer concussions but less likely to suffer intrusive luxation. These results are important, since the literature describes the intimate relationship between primary teeth and its successors [1]. Traumas that do not cause a change in tooth position in the arcade have less chance of sequelae in the permanent dentition [6].

\section{Conclusion}

Boys and children aged $0-3$ years suffer the most TDI. The most common cause is fall from own height; the most common place is in the home, and the support tissue is the most affected. Girls are significantly more prone to suffering concussions than boys. Children aged 4-6 years are more likely to suffer concussions and less likely to suffer intrusive luxation. Therefore, this study concludes that gender and age can be considered predisposing factors to the occurrence of some types of injuries in the primary teeth. 


\section{Authors' Contributions}

\begin{tabular}{|c|c|c|}
\hline TRCS & (iD) $0000-0001-8544-0627$ & $\begin{array}{l}\text { Methodology, Investigation, Formal Analysis, Writing - Original Draft } \\
\text { Preparation and Writing - Review and Editing. }\end{array}$ \\
\hline LAJ & (iD) $0000-0002-9772-1562$ & $\begin{array}{l}\text { Investigation, Formal Analysis, Writing - Original Draft Preparation and Writing } \\
\text { - Review and Editing. }\end{array}$ \\
\hline IS & (iD) $0000-0002-7859-2822$ & $\begin{array}{l}\text { Methodology, Investigation, Formal Analysis and Writing - Original Draft } \\
\text { Preparation. }\end{array}$ \\
\hline RRL & (iD) $0000-0002-7784-9905$ & Methodology, Formal Analysis and Writing - Original Draft Preparation. \\
\hline LAAA & (iD) $0000-0002-2115-6958$ & $\begin{array}{l}\text { Methodology, Investigation, Formal Analysis, Writing - Original Draft } \\
\text { Preparation and Writing - Review and Editing. }\end{array}$ \\
\hline PAR & (iD) $0000-0001-9550-8242$ & $\begin{array}{l}\text { Methodology, Investigation, Formal Analysis, Writing - Original Draft } \\
\text { Preparation and Writing - Review and Editing. }\end{array}$ \\
\hline $\mathrm{LCM}$ & (iD) $0000-0003-1026-9401$ & $\begin{array}{l}\text { Methodology, Investigation, Formal Analysis, Writing - Original Draft } \\
\text { Preparation and Writing - Review and Editing. }\end{array}$ \\
\hline
\end{tabular}

\section{Financial Support}

This study was financed in part by the Coordenação de aperfeiçoamento de pessoal de Nivel superior - Brasil (CAPES) Finance Code 001; Fundação Carlos Chagas Filho de Amparo à Pesquisa do Estado do Rio de Janeiro - FAPERJ E26/010.100992/2018; PIBIC / CNPq (121908/2019-4) and CNPq (159961/2018-1).

\section{Conflict of Interest}

The authors declare no conflicts of interest.

\section{Acknowledgement}

This study is part of the PhD thesis of Thais Rodrigues Campos Soares.

\section{References}

[1] Andreasen JO, Andreasen FM, Andersson L. Textbook and Color Atlas of Traumatic Injuries to the Teeth. 4th ed. Copenhagen: Munskgaard; 2007.

[2] Soriano EP, Caldas AF, Carvalho MVD, Amorim-Filho HA. Prevalence and risk factors related to traumatic dental injuries in Brazilian schoolchildren. Dent Traumatol 2007;2 3(4):232-40. https://doi.org/10.1111/j.1600-9657.2005.00426.x

[3] Abanto J, Paiva SM, Raggio DP, Celiberti P, Aldrigui JM, Bonecker M. The impact of dental caries and trauma in children on family quality of life. Community Dent Oral Epidemiol 2012; 40:323-31. https://doi.org/10.1111/j.1600-0528.2012.00672.x

[4] Abanto J, Carvalho TS, Mendes FM, Wanderley MT, Bönecker M, Raggio DP. Impact of oral diseases and disorders on oral health-related quality of life of preschool children. Community Dent Oral Epidemiol 2011; 39(2):105-14. https://doi.org/10.1111/j.1600-0528.2010.00580.x

[5] Lygidakis NA, Marinou D, Katsaris N. Analysis of dental emergencies presenting to a community paediatric dentistry centre. Int J Paediatric Dent 1998; (8):181-90. https://doi.org/10.1046/j.1365-263x.1998.00079.x

[6] Lenzi MM, Alexandria AK, Ferreira DM, Maia LC. Does trauma in the primary dentition cause sequelae in permanent successors? a systematic review. Dent Traumatol 2015; 31(2):79-88. https://doi.org/10.1111/edt.12149

[7] Cunha RF, Pugliese DMC, Vieira AEM. Oral trauma in Brazilian patients aged 0-3 years. Dent Traumatol 2001; 17(5):2 10-12. https://doi.org/10.1034/j.1600-9657.2001.170504.x

[8] Viegas CM, Scarpelli AC, Carvalho AC, Ferreira FM, Pordeus IA, Paiva SM. Predisposing factors for traumatic dental injuries in Brazilian preschool children. Eur J Paediatr Dent 2010; 11(2):59-65.

[9] EIKarmi RF, Hamdan MA, Rajab LD, Abu-Ghazaleh SB, Sonbol HN. Prevalence of traumatic dental injuries and associated factors among preschool children in Amman, Jordan. Dent Traumatol 2015; 31(6):487-92. https://doi.org/10.1111/edt.12183

[10] Tello G, Bonini GC, Murakami C, Abanto J, Oliveira LB, Bönecker M. Trends in the prevalence of traumatic crown injuries and associated factors in Brazilian preschool children: 10-year observational data. Dent Traumat 2016; 32:274-80. https://doi.org/10.1111/edt.12255 
[11] Kramer PF, Gomes CS, Ferreira SH, Feldens CA, Viana ES. Traumatismo na dentição decídua e fatores associados em pré-escolares do município de Canela/RS. Pesqui Bras Odontopediatria Clin Integr 2009; 9(1):95-100. https://doi.org/10.4034/1519.0501.2009.0091.0016 [In Portuguese].

[12] Kramer PF, Feldens EG, Bruch CM, Ferreira SH, Feldens CA. Clarifying the effect of behavioral and clinical factors on traumatic dental injuries in childhood: a hierarchical approach. Dent Traumatol 2015; 31(3):177-83. https://doi.org/10.1111/edt.12167

[13] Bonini GC, Bönecker M, Braga MM, Mendes FM. Combined effect of anterior malocclusion and inadequate lip coverage on dental trauma in primary teeth. Dent Traumatol 2012; 28(6):437-40. https://doi.org/10.1111/j.1600-9657.2012.01117.x

[14] Viegas CMS, Godoi PFS, Ferreira EF, Zarzar PMPA. Traumatism to the deciduous dentition: prevalence, etiological and predisposition factors. Arq Odontol 2006; 42(4):316-24.

[15] Feldens CA, Kramer PF, Feldens EG. Exploring the profile of articles on traumatic dental injuries in pediatric dental journals. Dent Traumatol 2013; 29(3):172-7. https://doi.org/10.1111/edt.12035

[16] Kramer PF, Onetto J, Flores MT, Borges TS, Feldens CA. Traumatic dental injuries in the primary dentition: a 15year bibliometric analysis of Dental Traumatology. Dent Traumatol 2016; 32(5):341-6. https://doi.org/10.1111/edt.12262

[17] Robson F, Ramos-Jorge ML, Bendo CB, Vale MP, Paiva SM, Pordeus IA. Prevalence and determining factors of Traumatic injuries to primary teeth in preschool children. Dent Traumatol 2009; 25(1):118-22. https://doi.org/10.1111/j.1600-9657.2008.00725.x

[18] Didem A, Alev A, Itır A, Gonca K. A retrospective study of traumatic dental injuries. Dent Traumatol 2014; 30:15461. https://doi.org/10.1111/edt.12057

[19] Jorge KO, Moysés SJ, Ferreira e Ferreira E, Ramos-Jorge ML, de Araújo Zarzar PM. Prevalence and factors associated to dental trauma in infants 1-3 years of age. Dent Traumatol 2009; 25(2):185-9. https://doi.org/10.1111/j.1600-9657.2008.00730.x

[20] Feldens CA, Kramer PF, Vidal SG, Faraco Junior IM, Vítolo MR. Traumatic dental injuries in the first year of life and associated factors in Brazilian infants. J Dent Child 2008; 75(1):7-13.

[21] Wendt FP, Torriani DD, Assunção MCF, Romano AR, Bonow MLM, Costa CT, et al. Traumatic dental injuries in primary dentition: epidemiologic study among preschool children in South Brazil. Dent Traumatol 2010; 26(2):16873. https://doi.org/10.1111/j.1600-9657.2009.00852.x

[22] Sousa DL, Neto JJSM, Filho JGB. Prevalência de trauma dental em crianças atendidas na Universidade Federal do Ceará. Rev Odonto Ciênc 2008; 23(4):355-9. [In Portuguese].

[23] Carvalho JC, Vinker F, Declereck D. Maloclusion, dental injuries and dental anomalies in the primary dentition of Belgian children. Int J Paediatr Dent 1998; 8(2):137-41. https://doi.org/10.1046/j.1365-263X.1998.00070.x

[24] Dutra FT, Marinho AM, Godoi PF, Borges CM, Ferreira EF, Zarzar PM. Prevalence of dental trauma and associated factors among 1-to 4-year-old children old children. J Dent Child 2010; 77(3):146-51. 